\title{
Observations on Phallocryptus spinosa (Branchiopoda, Anostraca) populations from the high plateaus of Northeastern Algeria
}

\author{
Mounia Amarouayache \\ Département des sciences de la mer, université Badji Mokhtar, Annaba, Algeria. \\ Email: m.derbal@yahoo.fr
}

Abstract

Phallocryptus spinosa (Thamnocephalidae) is a small primitive crustacean which lives in temporary saline pools of the Palaearctic region called Chott, Sebkha, Garâa or Daya in North Africa. Data on its biology and life history are very scarce despite its ecological importance in wetlands. Four populations living in the Northeastern High Plateaus of Algeria, Garâas Guellif, El-Tarf, Ank Djemel and Sebkha Ez-Zemoul, have been studied in point of view of their morphmetry (13 parameters) and their reproduction. The population of Sebkha Ez-Zemoul, living in higher salinities and in sympatry with Artemia salina was different from the 3 other populations that are close together. Its adults are the largest (21.77 $\pm 2.34 \mathrm{~mm}$ and $23.65 \pm 2.36 \mathrm{~mm}$ for males and females respectively) and produce more cysts $771.47 \pm 8.45$ cysts/brood of $293.11 \pm 10.41 \mu \mathrm{m}$ diameter. Associated carcinological fauna and some behavioral traits are also approached.

Key words: Phallocryptus spinosa, biometry, fecundity, associated fauna, Algeria.

Introduction

Large Branchiopods are considered as the flagship group of the ecosystems and the temporary pool invertebrates in general (Colbum, 2004). They are used for the assessment of their quality and function (Brendonck et al., 2008). They are threatened because of the degradation and the destruction of their habitats (IUCN France \& MNHN, 2012). 
Among Anostracan, the Thamnocephalid Phallocryptus spinosa (Milne-Edwards 1840) was long considered as Branchinella spinosa (Milne-Edwards 1840). Rogers (2003, 2006) gave a new description of the species and classified it in the genus Phallocryptus (Biraben 1951), which comprises three other species, of which P. tserensodnomi (Alonso \& Ventura, 2013) has been recently discovered in Mongolia. P. spinosa has a Palaearctic distribution which extends to the Botswana (Hulsmans et al., 2006) and Ukraine (Ketmaier et al., 2008). It lives in shallow (0.2 - $0.8 \mathrm{~m}$ ) saline (3 $300 \mathrm{psu}$ ) temporal lakes. Their females produce cysts to bridge period of drought ensuring the continuity of the species (Brendonk, 1996).

Studies on biological and behavioural aspects of P. spinosa are relatively scarce (Mura, 1992; Alonso, 1996; Brendonck \& Riddoch, 1997; Ampe \& Thiéry, 1998; Defaye et al., 1998) and generally concern their distribution and seasonality (Garcia et al., 1997; Thiéry \& Puff, 1998; Abatzopoulos et al., 1999; Mura, 1993; 2001; Vakili \& Sari, 2012). Recently Ketmaier et al., (2008) analyzed patterns of sequence divergence in mitochondrial DNA in 15 populations from the Mediterranean basin, Ukraine, Iran, Uzbekistan and Botswana concluding genetic differentiation among populations. The recent study of Alonso and Ventura (2013) showed that P. tserensodnomi from Mongolia was close to $P$. spinosa and might have some genotypes' of African populations.

P. Spinosa is known in Algeria from four large biotopes in the eastern High Plateaus (Samraoui et al., 2006) where it co-occurs with Artemia salina in Sebkha Ez-Zemoul (Amarouayache et al., 2012). It has been recorded in Boughzoul, an artificial lake of 1000 ha near the locality of Djelfa in the central High Plateaus by Beladjal et al., (1995). This species with Artemia (Artemiidae), govern the feeding and reproduction of the migratory birds, especially the Flamingo Phoenicopterus Ruber roseus (Samraoui \& Samraoui, 2008). The knowledge about this species is of great importance to envisage protection measures with regard of its ecological role. The aim of this study is to provide some data on biometry and reproduction of four populations among which one lives in sympatry with A. salina. Carcinological fauna living with P. spinosa was also identified, and other ecological observations are given.

Materials and methods

Sites and sampling: Phallocryptus spinosa and its associated fauna were sampled in the temporary pools (locally Sebkhas and Garâas) of the Northeastern High Plateaus (800-1000 m altitude), situated in a semi-arid region $(350-450 \mathrm{~mm}$ ) formed at the Pleistocene (Fig. 1). They are shallow $(\max 0.5 \mathrm{~m})$, alkaline $(\mathrm{pH}=8.5)$ and generally dried in summer. The thin water layer is led away by winds that generally blow from the Northwest. Sebkha Ez-Zemoul $\left(35^{\circ} 53^{\prime} \mathrm{N}-06^{\circ} 30^{\prime} \mathrm{E}\right)$ is the 
most saline (30-255 psu) with an area of 6,100 ha and is exploited for the salt by ENASEL farm. Garâa El-Tarf ( $\left.35^{\circ} 41^{\prime} \mathrm{N}-07^{\circ} 08^{\prime}\right)$ is the largest with 33,460 ha, then Garâa Ank-Djemel (35 ${ }^{\circ} \mathrm{N} 47^{\prime}$ $\left.06^{\circ} 51^{\prime}\right)$ with 6,700 ha and Garâa Guellif $\left(35^{\circ} 47^{\prime} \mathrm{N}-06^{\circ} 51^{\prime}\right)$ of 5,500 ha. These 3 Garâas have RAMSAR site statute. Their salinity at the sampling period was between 15 and 20 psu.

P. spinosa have been sampled in Sebkha Ez-Zemoul during an exceptional rainy year in January 2003 with $250 \mathrm{~mm}$ for this month, and $767.6 \mathrm{~mm}_{\text {.year }}{ }^{-1}$, a record rate during the 3 last decades. Water salinity has decreased at this period to $30 \mathrm{psu}$ and water column was $70 \mathrm{~cm}$ at the shore near the crystallizing ponds of the salt farm. In the 3 Garâas, individuals were sampled in May 2005 at the shore when water depth was around $2 \mathrm{~cm}$. A sieve of $125 \mu \mathrm{m}$ mesh vacuum was used to filtration and crustaceans were fixed in $4 \%$ formalin.

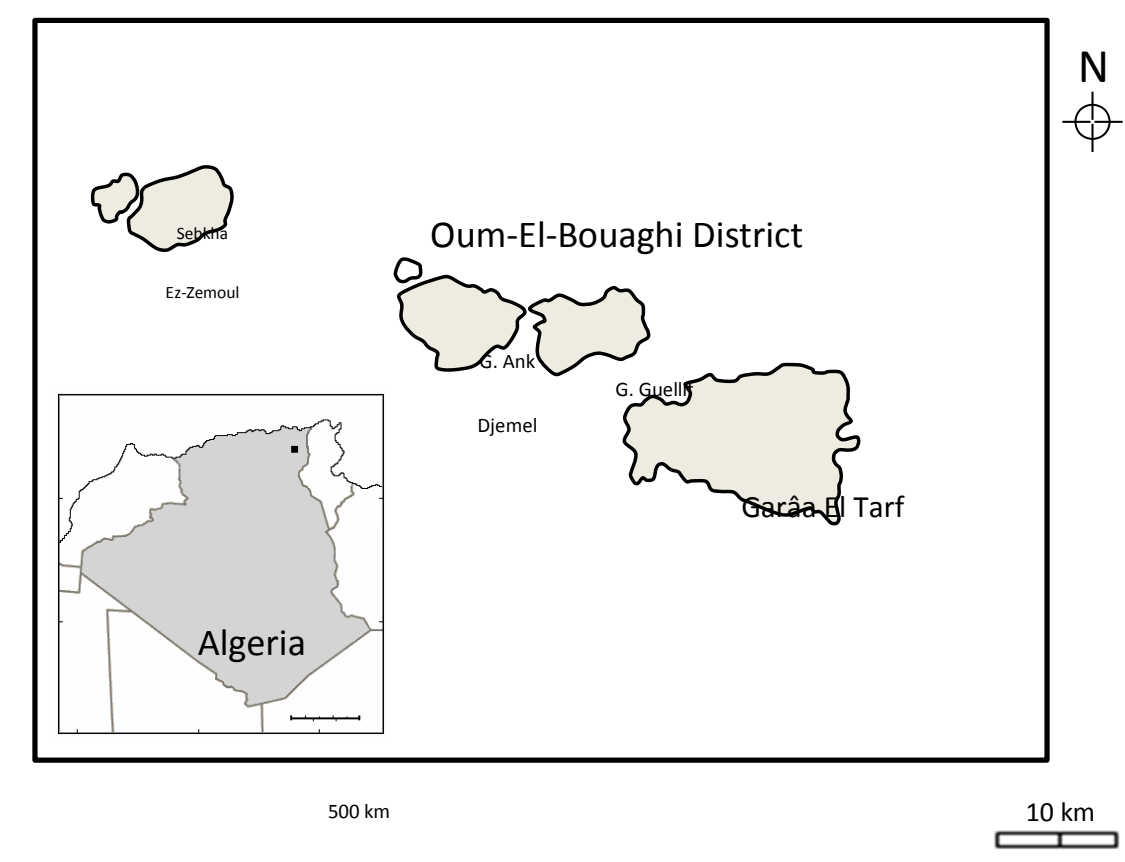

Figure 1. Geographic situation of sampling sites of Phallocryptus spinosa.

Biological and ecological observations: for each population, 20 males and 20 females have been measured using a compound microscope equipped with an ocular micrometer. One numeric (setae number) and 13 metric parameters have been considered for morphometric study according to Amat (1980, modified): total length, abdominal length, furca length, length of first antenna, length of ovisac, width of ovisac, width of the third abdominal segment, width of head, distance between complex eyes, maximal diameter of complex eye. The length and the width of the first abdominal spin were also considered. 
The size at first sexual maturity was determined as corresponding to the length of which $50 \%$ of the females presented signs of reproduction such as the presence of embryos or cysts inside the ovisacs. Those were dissected and the cysts were counted to determine fecundity. Cysts from each population were hydrated during $1 \mathrm{~h}$ and their mean diameter was measured. Other observations as the population structure and associated carcinological fauna were also approached.

\section{Results}

Reproduction and morphometry: all the females reproduce by oviparity and were gravid at a total length ranged between 11.5 and $23.65 \mathrm{~mm}$ according to the origin. Data on fecundity and mean diameter of hydrated cysts for each population are presented in table 1. Females of Sebkha Ez-Zemoul were the most fertile with a mean fecundity of $771.4 \pm 78.45$ cysts/brood and a maximal individual brood size of 888 cysts. In the 3 Garâas the fecundity was relatively low with a minimal brood size of $15.6 \pm 8.45$ cysts/brood observed in the Guellif's females. The mean diameter of hydrated cysts was comprised between $276.29 \pm 18.79 \mu \mathrm{m}$ and $293.11 \pm 10.41 \mu \mathrm{m}$ for Guellif and Ez-Zemoul respectively. Morphometric parameters are given in table 2. Populations of the three Garâas are close while individuals from Sebkha Ez-Zemoul clearly present larger lengths for all the parameters, except the setae number. Males' size was between $16.26 \pm 0.92$ and $21.77 \pm 2.34 \mathrm{~mm}$ for El-Tarf and EzZemoul's populations respectively and female's size was between $16.14 \pm 1.10$ and $23.65 \pm 2.36 \mathrm{~mm}$ and $21.77 \pm 2.34 \mathrm{~mm}$ for the same populations. Number of setae's was between a minimum of $96.50 \pm$ 24.28 observed in males of Garâa El-Tarf and a maximum of $125 \pm 14.26$ at females of Garâa Ank Djemel.

Table 1. Reproduction patterns for the Guellif, El-Tarf, Ank Djemel and Ez-Zemoul $P$. spinosa populations. L: Length at first sexual maturity, F: mean fecundity (SD), Cd: mean cyst diameter (SD), Min: minimal cyst diameter and Max: maximal cyst diameter.

\begin{tabular}{|c|c|c|c|c|}
\hline Parameter & Guellif & El-Tarf & An Djemel & Az-Zemoul \\
\hline $\mathrm{L} \mathrm{mm}$ & 14.00 & 13.00 & 11.50 & 23.65 \\
\hline F cysts/brood & $23 \pm 15.42$ & $15.6 \pm 8.45$ & $27.65 \pm 14.49$ & $771.47 \pm 8.45$ \\
\hline $\mathrm{Cd} \mu \mathrm{m}$ & $276.29 \pm 18.79$ & $292.18 \pm 21.81$ & $282.84 \pm 20.56$ & $293.11 \pm 10.41$ \\
\hline $\operatorname{Min} \mu \mathrm{m}$ & 239.20 & 208.00 & 239.20 & 266.00 \\
\hline $\operatorname{Max} \mu \mathrm{m}$ & 312.00 & 343.20 & 322.41 & 312.00 \\
\hline
\end{tabular}


Population structure and associated fauna: in the three Garâas, $P$. spinosa was present at high densities during the sampling period with an approximate density of 30,000 ind. $\mathrm{m}^{-2}$ near the banks. Adults dominated on juveniles and pre-adults at more than $90 \%$, and nauplii and metanauplii were totally absent. Sex-ratio was generally in favour of males with 1.02, 3.86, 2.09 and 1.87 in Garâas Guellif, El-Tarf, Ank-Djemel and Sebkha Ez-Zemoul respectively. In the Sebkha Ez-Zemoul $P$. spinosa was found with Artemia salina, the Harpacticoid Cletocamptus retrogressus (Schmankevitch, 1875), the Cladoceran Moina salina (Daday, 1888) and the Cypridid Ostracod Heterocypris sp. However, the majority of its individuals were dead, floating on the surface of the water and were brought from the other side of the Sebkha (North-East) by the waves. Some individuals carried almost entire Harpacticoids inside their abdomen, probably C. retrogressus (Fig. 2). P. spinosa of Garâa Guellif was found to live with M. salina witch was the most frequent, and rare individuals of the Ostracod Eucypris lilljeborgi and the Calanoid Arctodiaptomus salinus. In Garâa El-Tarf, A. salinus was the most frequent, then $C$. retrogressus, M. salina and a non-identified Ostracod. In Garâa Ank Djemel, M. salina was the most frequent with few non identified Ostracods.

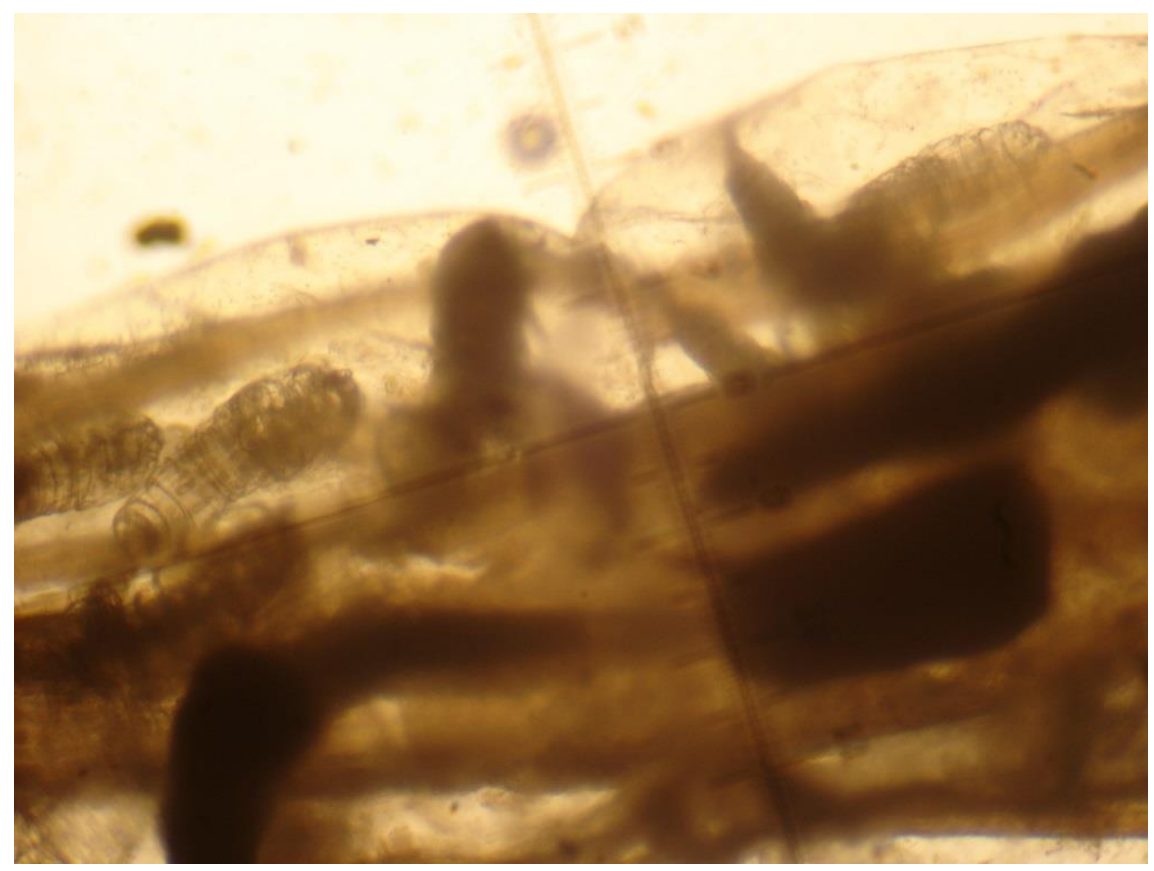

Figure 2. Photograph showing Harpacticoid Copepods inside the body of Phallocryptus spinosa from Sebkha Ez-Zemoul. 
Table 2. Mean (S.D.) of morphometric parameters of males and females in $\mathrm{mm}$ for the Guellif, El-Tarf, Ank Djemel and Ez-Zemoul P. spinosa populations. (A) total length, (B) abdominal length, (C) furca length, (D) length of first antenna, I length of ovisac, (F) width of ovisac, (G) width of the third abdominal segment, $(\mathrm{H})$ width of head, $(\mathrm{I})$ distance between complex eyes, $(\mathrm{J})$ maximal diameter of complex eye, $(\mathrm{K})$ length of the first abdominal spine, (L) width of the first abdominal spine, (M) number of setae.

\begin{tabular}{lcccc}
\hline Parameters & Guellif & El-Tarf & Ank Djemel & Ez-Zemoul \\
\hline A & $16.35(1.45)$ & $16.26(0.92)$ & $16.92(2.67)$ & $21.77(2.34)$ \\
& $16.25(1.64)$ & $16.14(1.10)$ & $17.84(2.65)$ & $23.65(2.36)$ \\
B & $8.87(0.78)$ & $9.31(0.52)$ & $9.35(1.49)$ & $11.82(1.24)$ \\
& $9.63(1.23)$ & $9.84(0.94)$ & $10.85(1.83)$ & $12.71(2.33)$ \\
C & $1.26(0.18)$ & $1.16(0.15)$ & $1.45(0.29)$ & $1.92(0.22)$ \\
& $1.06(0.27)$ & $0.88(0.13)$ & $1.28(0.31)$ & $2.02(0.19)$ \\
D & $1.80(0.17)$ & $1.63(0.22)$ & $1.60(0.35)$ & $2.08(0.35)$ \\
& $0.94(0.22)$ & $0.86(0.07)$ & $0.97(0.20)$ & $1.37(0.21)$ \\
E & $3.82(0.34)$ & $3.83(0.37)$ & $4.13(0.57)$ & $6.11(0.88)$ \\
F & $1.31(0.32)$ & $1.16(0.20)$ & $1.39(0.46)$ & $3.4(3.6)$ \\
G & $0.99(0.12)$ & $0.97(0.22)$ & $1.18(0.49)$ & $1.41(0.14)$ \\
& $0.95(0.15)$ & $0.86(0.14)$ & $1.17(0.24)$ & $1.79(0.24)$ \\
H & $1.11(0.33)$ & $0.90(0,09)$ & $1.04(0.18)$ & $1.35(0.18)$ \\
& $1.09(0.14)$ & $1.07(0.07)$ & $1.09(0.19)$ & $1.48(0.18)$ \\
I & $2.35(0.44)$ & $2.31(0.17)$ & $2.45(0.34)$ & $2.92(0.33)$ \\
& $2.07(0.32)$ & $2.05(0.19)$ & $2.17(0.34)$ & $3.00(0.32)$ \\
J & $0.65(0.09)$ & $0.65(0.08)$ & $0.64(0.11)$ & $0.89(0.09)$ \\
& $0.50(0.05)$ & $0.048(0.06)$ & $0.50(0.10)$ & $0.82(0.08)$ \\
K & $0.67(0.19)$ & $0.72(0.17)$ & $0.63(0.15)$ & $0.85(0.28)$ \\
L & $0.41(0.13)$ & $0.43(0.11)$ & $0.42(0.10)$ & $0.54(0.12)$ \\
& $107.55(14.76)$ & $96.5(24.28)$ & $112.1(13.49)$ & $99.19(28.76)$ \\
& $109.9(20.22)$ & $98.5(18.12)$ & $125.2(14.26)$ & $120.00(13.53)$ \\
\hline
\end{tabular}

Discussion

Phallocryptus spinosa lives in Algeria in biotopes much wider than those known from literature comprised between 5 and 135 ha (Garcia et al., 1997; Mura, 1999; Abatzopoulos et al., 1999, Moscatello et al., 2002; Mura \& Takami, 2002, Thiery \& Puente, 2002), except Tunisian Sebkhas of 
area's reaching 32,000ha (Ben Naceur et al., 2009). Adults of $P$. spinosa were dominant in the three Garâas while young stages were totally absent in May. It was certainly the last generation before the complete dry of the sites in summer. In Sebkha Ez-Zemoul, it was observed in January and cooccurred with Artemia salina but likely in the North-eastern side, from where dead individuals were brought by the waves. This co-existence, and also with other Anostracan, had been documented by several authors, in Greece (Mura \& Hadjistephanou, 1987), Italy (Mura, 1993, Moscatello et al., 2002), France (Defaye et al., 1998; Thiery \& Puente, 2002), Iran (Mura \& Takami, 2000), Botswana (Hulsmans et al., 2006) and Tunisia (Ben Naceur et al., 2009). It is considered as a complex phenomenon (Maeda-Martinez et al., 1997) complicating the adaptive strategies of these Anostraca life histories and leading to differences in the temporal or spatial distribution (Mura, 1993, Wang et al., 2012). The developing season for $P$. spinosa varies from a site to another. It was found in winter/spring in Tunisia (Ben Naceur et al., 2009), in May in the saline of the Southwest of Sardinia (Mura, 1993), between December and March In the temporary saline lake of Fuente de Piedra in Spain (Garcia et al., 1997) and between January and April in the French Camargue (Thiery \& Puente, 2002). Sex-ratio was in favour of males for all the studied populations as reported by Alonso (1996) for Spanish ones, while in Camargue, it was in favour of females (1:3) (Thiery \& Puente, 2002).

Total lengths between sexes are not different for Garâas populations, as it is the case for the populations of the Spanish Iberian Peninsula (Alonso, 1996). However, females from Sebkha EzZemoul which is more saline than the 3 others were larger than males, probably because the former should be stronger to carry males during mating when water density is high. Few biological data are available about biometry and reproduction. Alonso (1996) reported a maximal adults size of $40 \mathrm{~mm}$ for Spanish populations against $30 \mathrm{~mm}$ in the French Camargue (Defaye et al., 1998). Thiéry \& Puente (2002) found in the same population lengths which vary between 6 and $30 \mathrm{~mm}$. Mura (1993) found lower values of 6 to $11 \mathrm{~mm}$ in a Sardinian population. In point of view of biometrics, the three populations of Ank Djemel, Guellif and El-Tarf are close together but different from that of EzZemoul. Ketmaier et al. (2008) recently studied the phylogeography of the Paleartic species and found no differences between African populations of Algeria (Boughzoul) and that of Botswana. However, Alonso (1996) reported that $P$. spinosa could have two phenotypes according to its diet. Carnivorous individuals reach big sizes, but this predatory behavior is rarely observed in this species (Rogers, 2006). Entire Copepod's bodies were observed inside the abdomen of some P. spinosa individuals from Sebkha Ez-Zemoul, which could explain the gigantism in this population.

Females start to reproduce in general at a length of $11.5 \mathrm{~mm}$, which is close to that of the South-western Sardinian population (Mura, 1993). Oviparity was the unique mode of reproduction used as it is common in the species, and the females of Sebkha Ez-Zemoul were the most fertile among the studied populations (771 cysts/brood $v s<30$ cysts/brood). Alonso (1996) brought back a maximal fecundity of a thousand offspring in Spanish populations. Cyst diameter of the Northeast 
Algerian populations (276.29 - $292.18 \mu \mathrm{m}$ according to the origin) is close to that of Italian populations (Mura, 1992), and intermediate between that of the Camargue (220-265 $\mu \mathrm{m})$ (Defaye et al., 1998) and the Spanish populations (300 $\mu \mathrm{m})$ (Alonso, 1996).

Except the co-existence with Artemia, the carcinological fauna associated with $P$. spinosa has been rarely reported. This species lives in Spanish marshes, according to salinity and periods, with Moina salina, Cletocamptus retrogressus, Arctodiaptomus salinus, as it was found in this study, and also with Branchinectella media, Cyclops sp, Sigara sp, Macrothrix sp and Daphnia mediterranea Alonso 1985 (Garcia et al., 1997; Alonso \& Ventura, 2013). In Southern artificial saltmarshes of France, it lives with M. salina, C. retrogressus and Eurythemora velox (Thiery \& Puente, 2002).

\section{Bibliography}

Abatzopoulos, T.J., L. Brendonck, \& P. Sorgeloos, 1999. First record of Branchinella spinosa (MilneEdwards) (Crustacea: Branchiopoda: Anostraca) from Greece. International Journal of Salt Lake Research 8: 351-360.

Alonso, M 1996. Crustacea-Branchiopoda. In Fauna Iberica. Vol 7. Museo Nacional de Ciencias Naturales, Consejo Superior de Investigaciones Cientificas, Madrid, 486.

Alonso, M., \& M.Ventura, 2013. A new fairy shrimp Phallocryptus tserensodnomi (Branchiopoda: Anostraca) from Mongolia. Zootaxa, 3670: 349-361.

Amarouayache, M., F. Derbal, \& M.H. Kara, 2012. Note on the carcinological fauna associated to Artemia salina (Branchiopoda, Anostraca) from Sebkha Ez-Zemoul (Northeast, Algeria). Crustaceana, 85: 129-137.

Amat, F., 1980. Differenciation in Artemia strains from Spain : 19-39. In : the brine shrimp Artemia. Vol.1. Morphology, genetics, radiobiology, toxicology. Persoone, G.; Sorgeloos, P.; Roels, O. Jaspers, E. (eds). Universa Press, Wetteren, Belgium, 345 p.

Ampe, F. \& A. Thiéry, 1998. Microflora associated with the digestive tract of the fairy shrimp Branchinella spinosa (H. Milne-Edwards, 1840) (Crustacea Branchiopoda). FEMS Microbiology Letters, 1558: 201-205.

Beladjal, L., J. Mertens, \& H.J. Dumont, 1995. An analysis of the setation pattern of the limb in Anostraca (Crustacea); using the Algerian species as an example. Hydrobiologia, 298: 183-201. 
Ben Naceur, H., A. Ben Rejeb Jenhani, M. El-Cafsi, \& M. Romdhane, 2009. Note on the distribution of Branchinella spinosa (H. Milne Edwards, 1840) (Branchiopoda, Anostraca) in Tunisia. Crustaceana, 82: 635-641.

Brendonck, L. 1996. Diapause, quiescence, hatching requirements: what we can learn from large freshwater branchiopods (Crustacea; Branchiopoda, Anostraca, Notostraca, conchostraca). Hydrobiologia, 320: 85-97.

Brendonck, L. \& B.J. Riddoch, 1997. Anostracans (Branchiopoda) of Botswana: morphology, distribution, diversity and endemicity. Journal of Crustacean Biology, 17: 111-134.

Brendonck, L., D.C. Rogers, J. Olesen, S. Weeks, \& W.R. Hoch, 2008. Global diversity of large branchiopods (Crustacea: Branchiopoda) in freshwater. Hydrobiologia, 595: 167-176.

Colburn, E.A. 2004. Vernal pools, natural history and conservation. Mc Naughton \& Gunn, Inc., Salina, MI. 426 p.

Defaye, D., N. Rabet, \& A. Thiéry, 1998. Atlas et bibliographie des crustacés branchiopodes (Anostraca, Notostraca, Spinicaudata). MNHN, Paris. 62 pp.

Garcia C.M., R. Garci-Ruiz, M. Rendon, F.X. Niell, \& J. Lucena, 1997. Hydrobiological cycle and interannual variability of the aquatic community in a temporary saline lake (Fuente de Piedra, Southern Spain). Hydrobiologia, 345, 131-141.

Hulsmans, A., S. Bracke, K. Moreau, K., B,J. Riddoch., L. De Meester \& L. Brendonck, 2006. Dormant egg bank characteristics and hatching patterns of the Phallocryptus spinosa (Anostraca) population in the Makgadikgadi Pans (Botswana). Hydrobiologia, 271:123-132.

IUCN France \& MNHN, 2012. La liste rouge des espèces menaces en France. INPN, 25pp.

Ketmaier, V., D. Pirollo, E. De Matthaeis, R. Tiedemann, \& G. Mura, 2008. Large scale mitochondrial phylogeography in the halophilic fairy shrimp Phallocryptus spinosa (Milne-Edwards, 1840) (Branchiopoda Anostraca). Aquatic Sciences-Research Across Boundaries. 70: 65-76.

Maeda-Martinez, A. M., D. Belk, H. Oregon-Barboza, \& H.J. Dumont, 1997. Large branchiopod assemblages common to Mexico and the United States. Hydrobiologia, 359: 45-62.

Moscatello, S., G. Belmonte, \& G. Mura, 2002. The co-occurence of Artemia parthenogenetica and Branchinella spinosa (Branchiopoda: Anostraca) in a saline pond of south eastern Italy. Hydrobiologia 486: 201-206.

Mura, G., 1992. Preliminary testing of Anostraca from Italy for use in freshwater fish culture. Hydrobiologia 241: 185-194. 
Mura, G. 1993. Seasonal distribution of Artemia salina and Branchinella spinosa in a saline astatic pond in South West Sardinia, Italy (Anostraca). Crustaceana 64: 172-191.

Mura, G. 1999. Current status of the Anostraca (Crustacea, Branchiopoda) distribution in Italy. Journal of Limnology, 60: 45-49.

Mura, G. \& H. Hadjistephanou, 1987. First records of Branchinella spinosa (Milne-Edwards) (Crustacea, Anostraca) in Chyprus. Rivista di Idrobiologia, 26: 111-115.

Mura, G. \& G.A. Takami., 2002. A contribution to the knowledge of the anostracan fauna of Iran. Hydrobiologia, 441: 117-121.

Mura, G., 2001. Updating Anostraca (Crustacea, Branchiopoda) distribution on Italy. Journal of Limnology, 60: 45-49.

Rogers D.C., 2003. Revision of the Thamnocephalidae genus Phallocryptus (Crustacea: Branchiopoda: Anostraca). Zootaxa, 257, 1-14.

Rogers D.C., 2006. A genus level revision of the Thamnocephalidae (Crustacea: Branchiopoda: Anostraca). Zootaxa 1260: 1-25.

Samraoui, B., K. Chakri, \& F. Samraoui, 2006. Large branchiopods (Branchiopoda: Anostraca, Notostraca and Spinicaudata) from the salt lakes of Algeria. Journal of Limnology, 65: 83-88.

Samraoui, B. \& F. Samraoui, 2008. An ornithological survey of Algerian wetlands: Important Bird Areas, Ramsar sites and threatened species. Wildfowl, 58: 71-98.

Thiéry, A., \& L. Puente, 2002. Crustacean assemblage and environnemental characteristics of a manmade solar saltwork in southern France, with emphasis on anostracan (Branchiopoda) population dynamics. Hydrobiologia 486: 191-200.

Thiéry, A \& J.M. Puff, 1998. First find of Branchinella spinosa (H. Milne-Edwards, 1840) in a southern Frensh man-made saltwork. Crustaceana, 71: 223-227.

Vakili, B. \& A. Sari, 2012. The halophilic fairy shrimp Phallocryptus spinosa (Milne-Edward, 1840) (Crustacea: Branchiopoda: Anostraca) from Southeast Iran. Iranian Journal of Animal Biosystematics (IJAB), 8: 183-189.

Wang, C.C., S.L. Huang, W.P. Huang, \& L.S. Chou, 2012. Spatial niche differentiation of sympatric Branchiopoda in a highly unpredictable ephemeral pool. Journal of Crustacean Biology, 32: 39-47. 